\title{
Mútrágyahatások vizsgálata 7. éves telepített gyepen
}

\author{
KÁDÁR IMRE-RAGÁLYI PÉTER \\ MTA Talajtani és Agrokémiai Kutatóintézet, Budapest
}

\section{Összefoglalás}

Egy mútrágyázási tartamkísérlet 34. évében, 2007-ben vizsgáltuk az eltérō N, P, K ellátottsági szintek és kombinációik hatását a réti csenkesz (Festuca pratensis) vezérnövényú, nyolckomponensú, pillangós nélküli gyepkeverék termésére, fejlôdésére és $\mathrm{N}$-felvételére. Termôhely talaja a szántott rétegben mintegy 3\% humuszt, 3-5\% $\mathrm{CaCO}_{3}$-ot és 20-22\% agyagot tartalmazott, $\mathrm{N}$ és K elemekben közepesen, P és Zn elemekben gyengén ellátottnak minősült. A kísérlet $4 \mathrm{~N} \times 4 \mathrm{P} \times 4 \mathrm{~K}=64$ kezelést $\times 2$ ismétlést $=128$ parcellát foglalt magában. A talajvíz 13-15 m mélyen helyezkedik el, a terület aszályérzékeny. A gyep telepítése spenót elôvetemény után 2000. szeptember 20-án történt gabona sortávra $60 \mathrm{~kg} /$ ha vetőmaggal. Főbb eredményeink:

A száraz 2007. évben csak egy kaszálásra került sor. A 37 éve N-trágyázásban nem részesült talajon $0,5 \mathrm{t} / \mathrm{ha}$, a $300 \mathrm{~kg} / \mathrm{ha}$ /év N-adaggal trágyázott és P-ral is jól ellátott talajon 4,0 t/ha szénatermés képződött. Önmagában a P-trágyzás hatástalan maradt, de a Ntrágyázás hatékonysága is mérsékelt maradt a P-hiányos parcellákon. A K-ellátás növelése érdemi terméstöbblettel nem járt ezen a K-mal közepesen ellátott termóhelyen.

A N-kínálattal a legtöbb vizsgált elem (fémek, kationok) tartalma nôtt a szénában. A nagyobb terméssel előálló hígulás enyhén csökkentette a K, P és a S tartalmát. Érvényesült a nitrát-molibdenát antagonizmus, a N-bőség nyomán a Mo beépülése gátolt volt. A P-kínálat emelkedésével nôtt a P és S, illetve csökkent a Zn és Mo a szénában az ismert P-Zn, illetve foszfát-molibdenát antagonizmus miatt. A K-trágyázás a K-tartalmat emelte és igazolhatóan mérsékelte a Ca, $\mathrm{Mg}, \mathrm{Na}, \mathrm{Sr}$, Cu kationok és a B beépülését.

Az N és P elemek közötti kölcsönhatások eredményeképpen a P 0,14-0,40\%, S 0,130,23\%, a $\mathrm{NO}_{3}-\mathrm{N}$ 0,2-3,2 g/kg, Zn 12-23 mg/kg, Sr 10-24 mg/kg, Mo 0,5-2,3 mg/kg szélsô értékek között változott. Az $\mathrm{N}$ és $\mathrm{K}$ ellátottsági szinteken/kombinációkban a $\mathrm{K}$ 1,1-2,2\%, Ca 0,4-0,8\%, Na 0,1-1,5 g/kg, B 4-6 mg/kg tartományban volt. 
A tápelemarányok is jól jellemezték a széna tápláltsági állapotát. A nagy termés a 2\% feletti $\mathrm{N}$ és $0,2 \%$ feletti $\mathrm{P}$, tehát a 8-10 körüli N/P arányhoz volt köthetô. Itt az irodalmi utalásokkal összhangban termékeny talajon a $\mathrm{P} / \mathrm{Zn}$ aránya $100-150$, a $\mathrm{P} / \mathrm{NO}_{3}-\mathrm{N}$ aránya 200 körüli volt, míg a Cu/Mo aránya elérte a 10 körüli értéket. Az extrém N-hiányt jelezte a 3 körüli N/P aránya, a kifejezett Zn-hiányt a 300 feletti P/Zn aránya, valamint az erôsödô Cu-hiányt a 2 körülire szúkült $\mathrm{Cu} / \mathrm{Mo}$ aránya. Növényelemzéssel az indukált elemaránytalanságok feltárhatók, a tápláltsági állapot diagnosztizálható.

Az $\mathrm{N}$ és P ellátottság hatásaként a mért hektáronkénti elemfelvételek az alábbiak szerint alakultak: 5-96 kg N, 2-26 kg Ca, 2-11 kg P, 1-7 kg Mg, 0,1-8,0 kg NO $3-\mathrm{N}$. Ami a mikroelemeket illeti: 34-405 g Fe, 25-354 g Mn, 18-210 g Al, 5-95 g Sr, 7-89 g Zn, 2-20 g B, 1-15 g Ba és Cu, 0,7-4,0 g Mo, 0,1-1,4 g Ni, 0,01-0,11 g Cd hektáronként. Az As, $\mathrm{Hg}$, Cr, Se, Co g/ha kimutatási határ alatt maradt. A K 8-84 kg/ha, a Na 0,1-4,9 kg/ha, Mo 0,6-3,6 g/ha szélsó értékeket mutatta az $\mathrm{N}$ és K szintek függvényében.

A vizsgált pillangós nélküli gyepszéna fajlagos elemigénye 1 t széna előállításához kísérleti körülményeink között, eltekintve a szélső értékektől az alábbinak adódott: $10-23 \mathrm{~kg} \mathrm{~N}, 12-20 \mathrm{~kg} \mathrm{~K}\left(14-24 \mathrm{~K}_{2} \mathrm{O}\right), 4-6 \mathrm{~kg} \mathrm{Ca}(5-8 \mathrm{~kg} \mathrm{CaO}), 2-3 \mathrm{~kg} \mathrm{P}\left(4-7 \mathrm{~kg} \mathrm{P}_{2} \mathrm{O}_{5}\right)$ és $2 \mathrm{~kg}$ körüli $\mathrm{Mg}$ (3-4 kg MgO). Adataink iránymutatóul szolgálhatnak a tervezett termés elemigényének számításakor a szaktanácsadásban.

Kulcsszavak: telepített gyep, NPK mútrágyázás, szénatermés, elemtartalom

\title{
Examination of fertilisation effects on a 7-year-old established grassland
}

\author{
I. KÁDÁR-P. RAGÁLYI \\ Research Institute for Soil Science and Agricultural Chemistry of \\ the Hungarian Academy of Sciences, Budapest
}

\begin{abstract}
Summary
The effect of different levels of NPK supply and their combinations on the yield, development and $\mathrm{N}$ uptake of the eight-component grass mixture without papilionaceae in which meadow fescue (Festuca pratensis) was the dominant species was examined in 2007, the $34^{\text {th }}$ year of a long-term fertilisation experiment. The ploughed layer of the production
\end{abstract}


area contained 3\% humus, 3-5\% $\mathrm{CaCO}_{3}$ and $20-22 \%$ clay. The soil was moderately supplied with $\mathrm{N}$ and $\mathrm{K}$ and weakly supplied with $\mathrm{P}$ and $\mathrm{Zn}$. The experiment consisted of $4 \mathrm{~N} \times 4 \mathrm{P} \times 4 \mathrm{~K}=64$ treatments $\times 2$ replications $=128$ plots. The soil water level is $13-15 \mathrm{~m}$, the area is drought sensitive. The previous crop of grass was spinach and the grassland was established on $20^{\text {th }}$ September 2000 , using the row spacing of cereals at $60 \mathrm{~kg}$ sowing seed per hectare. The main results are as follows:

There was only one reaping in the dry year of 2007. There was $0.5 \mathrm{t} \mathrm{ha}^{-1}$ hay yield on the soil which has not been fertilised for 37 years, while $4.0 \mathrm{t} \mathrm{ha}^{-1}$ was obtained on the field which was fertilised with $300 \mathrm{~kg} \mathrm{ha}^{-1}$ year $^{-1} \mathrm{~N}$ and a satisfactory amount of $\mathrm{P}$. Phosphorus fertilisation was ineffective, but the efficacy of $\mathrm{N}$ fertilisation was also moderate on $\mathrm{P}$ deficient plots. The increase of $\mathrm{K}$ supply did not result in significant yield increase on this plot which was moderately supplied with $\mathrm{K}$.

The quantities of most examined elements (metals, cations) increased with K supply in hay. The dilution resulting from higher yield slightly decreased the K, P and S content. Nitrate-molybdenate antagonism was observed, while the incorporation of Mo was blocked as a result of $\mathrm{N}$ abundance. The quantity of $\mathrm{P}$ and $\mathrm{S}$ increased and the amount of $\mathrm{Zn}$ and Mo decreased in hay as the P supply increased due to the known P-Zn and phosphate - molybdenate antagonism. The $\mathrm{K}$ fertilisation increased the $\mathrm{K}$ content and significantly reduced the incorporation of $\mathrm{Ca}, \mathrm{Mg}, \mathrm{Na}, \mathrm{Sr}, \mathrm{Cu}$ cations and $\mathrm{B}$.

As a result of the interactions between $\mathrm{N}$ and $\mathrm{P}$, the amounts of the examined elements ranged between the following extreme values: $\mathrm{P} 0.14-0.40 \%, \mathrm{~S} 0.13-0.23 \%, \mathrm{NO}_{3}-\mathrm{N} 0.2-$ $3.2 \mathrm{~g} \mathrm{~kg}^{-1}$, Zn 12-23 $\mathrm{mg} \mathrm{kg}^{-1}$, Sr 10-24 $\mathrm{mg} \mathrm{kg}^{-1}$, Mo $0.5-2.3 \mathrm{mg} \mathrm{kg}^{-1}$. On the supply levels/ combinations of $\mathrm{N}$ and $\mathrm{K}$, the following ranges were observed $\mathrm{K} 1.1-2.2 \%$, Ca $0.4-$ $0.8 \%$, Na $0.1-1.5 \mathrm{~g} \mathrm{~kg}^{-1}$ and $\mathrm{B} 4-6 \mathrm{mg} \mathrm{kg}^{-1}$.

The observed nutrient proportions also characterised the nourishment status of hay. In the case of high yields, the amount of $\mathrm{N}$ was above $2 \%$, while that of $\mathrm{P}$ was above $0.2 \%$; therefore, the proportion of $\mathrm{N} / \mathrm{P}$ was around $8-10$. In accordance with the references, the $\mathrm{P} / \mathrm{Zn}$ ratio was $100-150$ on fertile soil, the ratio of $\mathrm{P} / \mathrm{NO}_{3}-\mathrm{N}$ was around 200 , while the proportion of $\mathrm{Cu} / \mathrm{Mo}$ was found to be around 10 . The extreme $\mathrm{N}$ shortage was shown by the fact that the ratio of $\mathrm{N} / \mathrm{P}$ was around 3, the significant $\mathrm{Zn}$ shortage was shown by the $\mathrm{P} / \mathrm{Zn}$ ratio which was above 300 , while $\mathrm{Cu}$ shortage was getting more and more severe, which was shown by the fact that the $\mathrm{Cu} / \mathrm{Mo}$ ratio decreased to around 2 . The induced element disproportions could be observed by crop analysis, and the nourishment status can be diagnosed.

As a result of the $\mathrm{N}$ and $\mathrm{P}$ supply, the following amounts of elements were taken up per hectare: 5-96 kg N, 2-26 kg Ca, 2-11 kg P, 1-7 kg Mg, 0.1-8.0 $\mathrm{kg} \mathrm{NO}_{3}$-N. As regards 
microelements, the following values were measured: 34-405 g Fe, 25-354 g Mn, 18-210 g Al, 5-95 g Sr, 7-89 g Zn, 2-20 g B, 1-15 g Ba and Cu, 0.7-4.0 g Mo, 0.1-1.4 g Ni, 0.01$0.11 \mathrm{~g} \mathrm{Cd}$ per hectare. The $\mathrm{g} \mathrm{ha}^{-1}$ levels of As, $\mathrm{Hg}$, Cr, Se, Co were below the detection level. Levels of $\mathrm{K}\left(8-84 \mathrm{~kg} \mathrm{ha}^{-1}\right), \mathrm{Na}\left(0.1-4.9 \mathrm{~kg} \mathrm{ha}^{-1}\right)$ and $\mathrm{Mo}\left(0.6-3.6 \mathrm{~g} \mathrm{ha}^{-1}\right)$ showed extreme values concerning $\mathrm{N}$ and $\mathrm{K}$ levels.

The specific element need of the examined grass hay without papilionaceae for the production of $1 \mathrm{t}$ hay under the given experimental conditions, excluding extreme values was shown to be the following: $10-23 \mathrm{~kg} \mathrm{~N}, 12-20 \mathrm{~kg} \mathrm{~K}\left(14-24 \mathrm{~K}_{2} \mathrm{O}\right), 4-6 \mathrm{~kg} \mathrm{Ca}$ (5-8 $\mathrm{kg} \mathrm{CaO}), 2-3 \mathrm{~kg} \mathrm{P}\left(4-7 \mathrm{~kg} \mathrm{P}_{2} \mathrm{O}_{5}\right.$ ) and around $2 \mathrm{~kg} \mathrm{Mg}(3-4 \mathrm{~kg} \mathrm{MgO}$ ). These data could be informative in the technical advice system during the calculation of the element need of the planned yield.

Key words: established grassland, NPK fertilisation, hay yield, mineral elements

\title{
Исследование влияния искусственного удобрения на семилетнем, посеянном дёрне
}

\author{
И. КАДАР-П. РАГАИ
}

Исследовательский Институт Почвоведения и Агрохимии Венгерской Академии Наук, Будапешт

\section{Резюме}

На 34-ом году продолжительного опыта искусственных удобрений, в 2007 году исследовали влияние различных уровней обеспечения N, P, K и их комбинаций на урожай, развитие и принятие $\mathrm{N}$ восьмикомпонентных, безбобовых дерновых смесей, с главным растением луговой овсяницей (Festuca pratensis). Почва места выращивания во вспаханном слое содержала всего 3\% гумуса, 3-5\% $\mathrm{CaCO}_{3}$ и 20-22\% глины, средне снабженна элементами $\mathrm{N}$ и $\mathrm{K}$, а элементами $\mathrm{P}$ и Zn слабо обеспеченна. Опыт представлял собой $4 \mathrm{~N} \times 4 \mathrm{P} \times 4 \mathrm{~K}=64$ обработки $\times 2$ повторения=128 парцеллы. Грунтовые воды расположены на глубине 13-15 m, территория чувствительна к засухе. Посев дёрна проведен после шпината предшественника 20-го сентября 2000 года посевным материалом $60 \mathrm{~kg} / \mathrm{ha}$ при зерновых междурядьях. Главные результаты: 
В сухой 2007 год был только один покос. На почве, где 37 лет не применяли удобрения $\mathrm{N}$ образовался урожай сена $0,5 \mathrm{t} / \mathrm{ha}$, а на удобрённой дозами $\mathrm{N} 300 \mathrm{~kg} / \mathrm{ha} /$ год и хорошо обеспеченной Р почве получили урожай сена $4,0 \mathrm{t} / \mathrm{ha}$. Применение одного только удобрения $\mathrm{P}$ было неэффективным, но и эффективность удобрения $\mathrm{N}$ также была умеренной на парцеллах с недостатком Р. Рост обеспеченности К не принес существенной прибавки урожая на этом средне обеспеченном К месте выращивания.

С предложением $\mathrm{N}$ содержание большинства исследованных элементов (металлы, катионы) в сене выросло. Образовавшееся с большим урожаем разжижение немного сократило содержание $\mathrm{K}$, Р и S. Проявился антагонизм нитрат-молибден, в результате изобилия $\mathrm{N}$ приём Мо был ограниченным. С ростом доз Р увеличилось содержание $\mathrm{P}$ и $\mathrm{S}$, а также уменьшилось содержание $\mathrm{Zn}$ и Мо в сене из-за известного антагонизма P-Zn, и из-за антагонизма фосфат-молибден. Внесение удобрения $\mathrm{K}$ увеличило содержание $\mathrm{K}$ и доказуемо уменьшило приём катионов $\mathrm{Ca}, \mathrm{Mg}$, $\mathrm{Na}$, $\mathrm{Sr}, \mathrm{Cu}$ и $\mathrm{B}$.

В результате взаимовлияний элементов $\mathrm{N}$ и $\mathrm{P}$ изменилось содержание $\mathrm{P}$ в пределах $0,14-0,40 \%$, S в пределах $0,13-0,23 \%, \mathrm{NO}_{3}$ - $\mathrm{N}$ в пределах $0,2-3,2 \mathrm{~g} / \mathrm{kg}, \mathrm{Zn}$ в пределах 12-23 mg/kg, Sr в пределах 10-24 mg/kg, Мо в пределах 0,5-2,3 mg/kg. На уровнях обеспечения/в комбинациях $\mathrm{N}$ и К наблюдалось К в пределах $1,1-2,2 \%, \mathrm{Ca}$ в пределах 0,4-0,8\%, Na в пределах $0,1-1,5 \mathrm{~g} / \mathrm{kg}$, В в пределах $4-6 \mathrm{mg} / \mathrm{kg}$.

Соотношения питательных элементов также хорошо характиризовали состояние упитанности сена. В большом урожае можно обнаружить выше $2 \% \mathrm{~N}$ и выше $0,2 \%$ P, т.е. приблизительно 8-10 кратное соотношение N/P. Здесь в соответствии с литературными упоминаниями на продородной почве соотношение $\mathrm{P} / \mathrm{Zn}$ достигло уровня $100-150$, соотношение $\mathrm{P} / \mathrm{NO}_{3}$ - $\mathrm{N}$ было около 200 , а соотношение $\mathrm{Cu} / \mathrm{Mo}$ достигло показатель около 10. Экстремальный дифицит $\mathrm{N}$ означала величина 3 в отношении $\mathrm{N} / \mathrm{P}$, выраженный дифицит $\mathrm{Zn}$ означало соотношение выше $300 \mathrm{P} / \mathrm{Zn}$, и растущий дифицит $\mathrm{Cu}$ показывало сокращённое примерно до 2 соотношение $\mathrm{Cu} / \mathrm{Mo}$. Анализом растений можно обнаружить индукцированные непропорциональности элементов, можно диагностировать состояние их упитанности.

Под влиянием обеспеченности $\mathrm{N}$ и Р измеренные погектарно приёмы элементов сформировались следующим образом: 5-96 kg N, 2-26 kg Сa, 2-11 kg P, 1-7 kg $\mathrm{Mg}, 0,1-8,0 \mathrm{~kg} \mathrm{NO}_{3}$-N. Микроэлементы следующим образом: 34-405 g Fe, 25-354 g Mn, 18-210 g Al, 5-95 g Sr, 7-89 g Zn, 2-20 g B, 1-15 g Ва и Cu, 0,7-4,0 g Mo, 0,1$1,4 \mathrm{~g} \mathrm{Ni}, 0,01-0,11 \mathrm{~g} \mathrm{Cd}$ погектарно. As, $\mathrm{Hg}, \mathrm{Cr}$, Se, Co g/ha остались ниже уровня выявления. В зависимости от уровня $\mathrm{N}$ и К показали крайние величины K $8-84 \mathrm{~kg} / \mathrm{ha}$, Na 0,1-4,9 kg/ha, Mo 0,6-3,6 g/ha. 
Удельная потребность в элементах исследованного дернового безбобового сена для производства $1 \mathrm{t}$ сена в опытных условиях,не учитывая крайние показатели получилась следующая: 10-23 kg N, 12-20 kg K (14-24 K 20 ), 4-6 kg Са (5-8 kg СaO), 2-3 kg Р (4-7 kg Р $\mathrm{O}_{5}$ ) и около $2 \mathrm{~kg} \mathrm{Mg}$ (3-4 kg MgO). Наши данные могут использоваться как указатели в рекомендациях при вычислении потребности в элементах планируемого урожая.

Ключевые слова: посеянный дёрн, внесение искусственных удобрений NPK, урожай сена, содержание элементов

\section{Bevezetés és irodalmi áttekintés}

A gyep termóképességét döntóen meghatározza a víz- és tápanyagellátás. Németországi tapasztalatok szerint, ha a talajvíz nem hozzáférhető, jó vízgazdálkodású termóhelyen mintegy 700 mm, homokon legalább 1000 mm csapadékot igényelhet a nagy termés. A sekélyen gyökerező gyep számára hozzáférhetô a talajvíz, kötöttebb talajon 60-90 cm, könnyú talajon $40 \mathrm{~cm}$ mélységben (Geisler 1988). Hazai viszonyok között 1 kg szárazanyag előállításához Gyarmathy (1980) szerint átlagosan 600 liter vizet párologtat el a gyep, de vízszükséglete extrém esetben 400-1200 1/kg szárazanyag között ingadozhat. Gruber (1960) vizsgálataiban azt találta, hogy 1 kg szárazanyaghoz a gyep 520$790 \mathrm{~kg}$ vizet használt fel. Szabó (1977) szerint a trágyázással, fóként a N adagolásakor, nôhet a termés tömege és látványosan javulhat a vízhasznosulás.

Klímatényezők közül a fényt is teljes mértékben képes hasznosítani, hiszen egész évben szinte teljes borítottságot biztosít. A növekedés már kora tavasszal $5{ }^{\circ} \mathrm{C}$ felett megindulhat, maximumát $15-25^{\circ} \mathrm{C}$-on áprilisban, májusban éri el. Ezt követốen a nyári hónapokban a gyep „pihen”, ôszi időszakban is csak mérsékelt fejlődést mutat. A kaszálások gyengítik az állományt, gyengül a gyökérnövekedés, a tápanyagok felhalmozása a gyökérben, illetve a regenerációs képesség. A gyakori vágásnál kiszorulnak, gyérülhetnek a nagytestú szálfüvek (Bíró 1928, Klapp 1951, Gruber 1960, Baskay 1962, Szabó 1977, Vinczeffy 1998).

A N főként a szálfüveket növeli, illetve a pillangósokat leárnyékolja és elnyomja. Ezzel részben csökkenti a gyep Ca és Mg készletét. Más oldalról viszont a $\mathrm{N}$, alapvetôen a $\mathrm{NO}_{3}$-forma növelheti a kationok beépülését a növénybe, amennyiben a talaj kellôen ellátott ezen elemekben. Ellenkezô esetben hígulási 
effektus érvényesülhet: termés nő, az egyéb kationok, elemek koncentrációja csökken (Raymond és Spedding 1965). A N-hatás természetszerúen a here nélküli gyepen kiemelkedô. Általában késlelteti az érést, öregedés ellen hat, növeli a víztartalmat, nyersfehérje és az emészthetôség \%-át, ezzel arányosan csökkenti a nyersrost tartalmát (Klapp 1971, Szabó 1977, Barcsák 1999). McLean et al. (1956) rámutatott arra is, hogy a gyökerek kationcserélő kapacitása, felvevơképessége nô a $\mathrm{N}$-tartalmukkal.

Esetenként a P minimumtényezô, fốként a pillangósok számára. Gericke $(1957,1965) 1270$ mintát elemezve arra a következtetésre jutott, hogy a széna $0,65 \% \mathrm{P}_{2} \mathrm{O}_{5}(0,28 \mathrm{P} \%)$ készlete kielégító P-ellátottságot tükrözhet. Mivel a $\mathrm{P}$ nemkívánatos luxusfelvételt gyakorlatilag nem mutat, célszerú Wagner (1909, 1921) klasszikus tanácsát követni. A talajokat P-ral fel kell tölteni, majd ezt követôen vágásonként a terméssel felvett $\mathrm{P}$-t pótolni, a talaj termékenységét fenntartva. Így kedvezóen érvényesülhet a N-mútrágya és elkerülhető a növényben a káros $\mathrm{NO}_{3}$-N akkumulációja. Itthon Harmati $(1981,1997)$ kapott kiugrónak minôsüló P és NP hatásokat szikes réti talajon, illetve legutóbb Bánszki (1988, 1997) hívta fel a figyelmet tápelemarányok kérdésére.

A talaj K kínálata összefügg kötöttségével, kolloidkészletével. Kötött termôhelyen hosszú évekig nagy terméseket kaphatunk K-trágyázás nélkül. Hiánya esetén a P-hoz hasonlóan célszerú talajgazdagító/feltöltô K-trágyázást folytatni, majd vágásonként pótlással a talaj K-készletét fenntartani. Wagner (1921) szerint K-mal a gyep ,jóllakott”, ha a füvek legalább $2 \% \mathrm{~K}_{2} \mathrm{O}$ tartalommal rendelkeznek. Romasev (1960) is utal arra a körülményre, hogy a telepítés évében a gyökerek fejlódése meghatározó lehet. A tartalék tápanyagok itt halmozódnak fel, így pl. esetenként a N 60-80\%-át a gyökerekben találjuk, és csak 20-40\%-át a hajtásban. Döntố ezért az alapozó trágyázás a gyep további termelékenysége szempontjából.

Az elmúlt évtizedekben igyekeztünk minden fontosabb szántóföldi növényfaj agrokémiájával foglalkozni és feltárni a tápláltsági állapot, valamint a termés, terméselemek, ásványi összetétel, gyomosodás, betegség-ellenállóság, minőségi jellemző́k közötti számszerú összefüggéseket, megismerni a növényi és talajbani optimumokat, orientálni a szaktanácsadást. A kísérlet elsố 2 évtizedének foobb eredményeit „A növénytáplálás alapelvei és módszerei” c. kézikönyv (Kádár 1992) foglalta össze. Az egyes években nyert kísérleti adatok növényfajonként megjelentek, illetve megjelennek a Növénytermelés, illetve az Agrokémia és Talajtan c. folyóiratok hasábjain. 
A gyeppel kapcsolatos elsô munkánkban ismertettük részletesen a kísérletünk módszerét, körülményeit, illetve a gyeptrágyázással összefüggô fontosabb hazai és külföldi forrásokat. Bemutattuk az eltérô tápláltsági szintek és kombinációik hatását a telepített gyep fejlődésére, elsố évének terméseire, N-felvételére és a N-mútrágyák hasznosulására. Második közleményünk a takarmányérték vizsgálat módszertanát, irodalmát, valamint a gyepszéna minóségének változásait tekintette át a tápláltsági szintek függvényében kísérletünkben (Kádár és Gyốri 2004). Külön dolgozat taglalta a széna fontosabb makro- és mikroelemeinek akkumulációját, a lehetséges kölcsönhatásokat az egyes elemek felvétele során. A nemzetközi és a hazai irodalom bázisán értékelte azokat a diagnosztikai optimumokat, melyek a növénytáplálás, illetve a takarmányozás számára iránymutatóak lehetnek (Kádár 2004).

Vizsgáltuk a gyepszéna makro- és mikroelemeinek felvételét a tápláltsági szituáció függvényében és meghatároztuk az 1 t széna képzôdéséhez szükséges átlagos fajlagos elemigényt, mely a tudományosan megalapozott trágyázási szaktanácsadás alapjául szolgálhat. Hasonló átfogó, 20-25 elemre kiterjedô elemforgalmi vizsgálatok a hazai szakirodalomban hiányoztak. A takarmányozástannal foglalkozó tudomány fejlődését is érintve, értékeltük a mútrágyázás hatását a gyep aminosav tartalmára és hozamára. Bemutattuk, hogy a kiegyensúlyozatlan ásványi táplálás, illetve mútrágyahasználat milyen mérvú egyensúlytalanságot hozhat létre az egyes aminosav-párok között a fellépó antagonizmusok nyomán (Kádár és Győri 2005).

A kísérlet 2. évének nagytömegú adatát külön értékeltük a termés és elemösszetétel, az ásványi elemforgalom, valamint a minőség és tápanyaghozam tekintetében. A kísérlet 3. évében 2003-ban az aszályos nyár miatt csak egyetlen kaszálásra került sor. Utóbbi közleményünk a hiányos, optimális és túlsúlyos vagy egyoldalú ásványi táplálás hatásait mutatta be a gyepszéna termésére, minőségi jellemzőire, elemösszetételére és elemforgalmára. A 4. és 5 . éves mútrágyahatások eredményeit is közöltük, áttekintve a termés és az ásványi összetétel valamint az elemforgalom (Kádár 2008, 2010) alakulását. Jelen munkánk a 7. éves mútrágyahatások eredményeit foglalja össze, áttekintve a termés és az ásványi összetétel alakulását.

Különös figyelmet fordítunk a tápelemarányok változására. Így pl. a P/Zn arány optimuma 50-150 közötti. Irodalmi utalások és saját vizsgálataink szerint is a 250-300 feletti $\mathrm{P} / \mathrm{Zn}$ arány esetén a Zn-trágyázás hatékony lehet (Bergmann 1992, Kádár 1992, Csathó 1992, 2004). 
Rámutattunk arra, hogy a tartós mútrágyázás milyen drasztikus beavatkozást jelenthet a talajba és a rajta termó növénybe az antagonizmusok és szinergizmusok nyomán. Egy elem túlsúlya egyidejúleg hiányt jelent más elem tekintetében. Az optimális összetétel biztosíthatja a megfelelô minóséget, mely fenntartja a normális anyagcserét növényben, állatban, emberben. Az ellenőrizhetetlen, szakszerútlen mútrágyahasználat súlyos következményekkel járhat, melyre franciahoni példákon korábban már Voisin (1961, 1964, 1965) és Tölgyesi (1965) rámutatott.

Itthon legutóbb Mucsi (1996) hívta fel a figyelmet arra, hogy a legeló állatok „veleszületett” anyagcsere betegségei gyakran talajeredetúek. A szerzó szerint Európában napjainkra megsokszorozódtak az ilyen jellegú problémák. Nagy (2008) a környezeti tényezôk szerepét hangsúlyozta a gyepek fejlődésében, különös tekintettel a csapadékra. A tartós N-mútrágyázás pl. Cu-hiányt indukálhat rézzel gyengén ellátott termőhelyen, melynek következménye lehet az anémia, hasmenés, meddóség, stb. A fúben kívánatos közismerten a 8-12 $\mathrm{mg} / \mathrm{kg}$ sz. a. Cu-tartalom. Ezen túlmenôen kulcsfontosságú a Cu/Mo optimális 5-10 feletti aránya. A Mo túlsúlya Cu-hiányt okozhat, ekkor pl. az E-vitamin szintézise is gátolt. Tehát: „Az állat (ember) biológiai fényképe annak a környezetnek ahol él. Különösen annak a talajnak, amely megtermi a takarmányt (táplálékot) az organizmus számára."

A kísérlet 33 éve alatt $0,3200,6400,9600 \mathrm{~kg} / \mathrm{ha} \mathrm{N}$-t használtunk fel. A növények által fel nem vett $\mathrm{N} 40-60 \%$-át $\mathrm{NO}_{3}-\mathrm{N}$ formában tudtuk korábban kimutatni a túltrágyázott talajon. Az idônként végzett mélyfúrásaink szerint a $\mathrm{NO}_{3}-\mathrm{N}$ $20-30 \mathrm{~cm} /$ év sebességgel szivároghat lefelé, a kísérlet 17. illetve 22. éve után a bemosódás mélysége elérte e termőhelyen a $6 \mathrm{~m}$ mélységet (Németh és Kádár 1999). Megemlítjük, hogy 2001-ben az 1 éves gyep alatt a feltalaj $\mathrm{NO}_{3}$-N készlete drasztikusan lecsökkent, még a $300 \mathrm{~kg} / \mathrm{ha}$ /év N kezelésekben is, ami visszavezethetố jelentôs részben a növénybe épült hatalmas $\mathrm{N}$-mennyiségekre. A két kaszálással felvett N földfeletti mennyisége megközelítette a $400 \mathrm{~kg} / \mathrm{ha}$ tömeget. Akár hasonló lehetett a gyökerekbe épült $\mathrm{N}$ mennyisége is (Kádár et al. 2010).

\section{Anyag és módszer}

A kísérletet 1973 ószén állítottuk be Mezőföldön, az MTA TAKI nagyhörcsöki kísérleti telepén. A termôhely löszön képződött karbonátos csernozjom talaja a szántott rétegben mintegy 3-5\% $\mathrm{CaCO}_{3}$-ot és 3\% humuszt tartalmaz. A 
$\mathrm{pH}(\mathrm{KCl}) 7,3$, az AL- $\mathrm{P}_{2} \mathrm{O}_{5} 60-80 \mathrm{mg} / \mathrm{kg}$, AL- $\mathrm{K}_{2} \mathrm{O} 140-160$ mg/kg, KCl-oldható Mg 150-180 mg/kg. Ami a KCl+EDTA-oldható mikroelemeket illeti a Mn 80$150 \mathrm{mg} / \mathrm{kg}$, a Cu 2-3 mg/kg, a Zn 1-2 mg/kg értékkel jellemezhetô. A hazai szaktanácsadásunkban irányadó határértékek alapján ezek az adatok igen jó Mn, kielégítő Mg és Cu, közepes $\mathrm{N}$ és $\mathrm{K}$, valamint gyenge $\mathrm{P}$ és Zn ellátottságról tanúskodnak. A talajvíz szintje 13-15 m mélyen található, a kísérleti terület az Alföldhöz hasonlóan aszályérzékeny.

A N-t megosztva, felét ôsszel, felét tavasszal alkalmaztuk pétisó formájában $0,100,200,300 \mathrm{~kg} / \mathrm{ha}$ /év N-adagban. A P és K trágyázás $0,500,1000,1500 \mathrm{~kg} / \mathrm{ha}$ $\mathrm{P}_{2} \mathrm{O}_{5}$, illetve $\mathrm{K}_{2} \mathrm{O}$ adaggal történik, 5-10 évente ismételve a feltöltést. Legutóbb 1999 ôszén végeztünk PK feltöltô trágyázást. A N, P és K mútrágyákat 4-4 szinten adagolva 1973 ôszén minden lehetséges kombinációt beállítottunk $4 \mathrm{~N} \times 4 \mathrm{P}=16 \times 4 \mathrm{~K}=64$ kezelés $\times 2$ ismétlés $=128$ parcellában. A parcellák mérete $6 \times 6=36 \mathrm{~m}^{2}$, elrendezésük kevert faktoriális. A kísérleti terv, illetve az alkalmazott mútrágyázás lehetôvé tette, hogy valamennyi olyan tápláltsági állapotot (gyenge, közepes, kielégító, túlzott) és azok változatait létrehozzuk, amelyek a gyakorlatban is elófordulnak, vagy táblaszinten a jövóben előfordulhatnak.

A 3 évtized alatt $0,1500,3000,4500 \mathrm{~kg} / \mathrm{ha}_{2} \mathrm{O}_{5}$, illetve $2500,5000,7500$ $\mathrm{kg} / \mathrm{ha} \mathrm{K}_{2} \mathrm{O}$ felhasználásra került sor, mely tükröződik a feltalaj ammóniumlaktát oldható PK-készletén. Egyaránt megtalálható a gyenge, közepes, igen jó és a káros P-ellátottság. Hasonló a helyzet a talaj mobilis K-készletét illetôen. Talajvizsgálatokat 2005 ôszén végeztünk. A kísérletben alkalmazott kezeléseket és a talaj szántott rétegének oldható elemtartalmát az 1. táblázat tekinti át.

A gyep telepítését a kísérlet 28. évében a spenót betakarítása után (2. táblázat) 2000. szeptember 20-án végeztük el 8 komponensből álló gyepvetômag keverékével. Vetőmag a Szarvasi Gyepnemesítő Telep (Bikazug) 1999. évi terméséből származott. A viszonylag sok komponens azt a célt szolgálta, hogy kellô borítottság alakulhasson ki, és tájékozódjunk arról, mely fajok alkalmasak e termóhelyre.

Amint a 3. táblázatban látható, vezérnövényünk a réti csenkesz 35\%-kal, 21\%-ot képvisel a nádképú csenkesz és az angol perje, 9\%-ot a taréjos búzafú, egyenként 6\%-ot pedig a vörös csenkesz, réti komócsin, zöld pántlikafú és a csomós ebír. A vezérnövény virágzása elốtti stádiumban 2001-ben, 2002-ben és 2004-ben 2-2 kaszálást végeztünk, míg a szárazabb 2003. évben csak egy kaszálásra került sor. A parcellák szegélyétôl 1,4 m-eket jobbról és balról lehagyva $3,2 \times 6=19,2 \mathrm{~m}^{2}$ nettó parcellák területét értékeltük az eke általi talajáthordás ha- 
tásának kizárása céljából. Laboratóriumi vizsgálatokra, parcellánként 20 helyrôl a fúkasza után, átlagmintákat vettünk. Mintáknak mértük a friss és légszáraz tömegét $\left(50{ }^{\circ} \mathrm{C}\right.$-on történt szárítást követôen), majd finomra ôröltük és 2325 elemre vizsgáltuk cc. $\mathrm{HNO}_{3}+\mathrm{cc}_{2} \mathrm{H}_{2} \mathrm{O}_{2}$ roncsolás után, ICP technikát alkalmazva. A N-tartalmat hagyományos cc. $\mathrm{H}_{2} \mathrm{SO}_{4}+\mathrm{cc} \cdot \mathrm{H}_{2} \mathrm{O}_{2}$ feltárásból határoztuk meg. $\mathrm{A} \mathrm{NO}_{3}$-N készletét 1:800 arányú desztillált vizes kivonatból mértük Thammné (1990) által ajánlott módszerrel.

1. táblázat. Kezelések és hatásuk a talaj szántott rétegének AL-oldható elemkészletére 2005-ben

(Karbonátos csernozjom vályogtalaj, Nagyhörcsök, Mezóföld)

\begin{tabular}{|c|c|c|c|c|c|c|}
\hline \multirow{2}{*}{$\begin{array}{c}\text { Mútrágyázás és } \\
\text { talajvizsgálat } \\
\text { (1) }\end{array}$} & \multicolumn{4}{|c|}{$\begin{array}{l}\text { Kezelések, illetve mútrágyázási szintek } \\
\text { (2) }\end{array}$} & \multirow{2}{*}{$\begin{array}{l}\mathrm{SzD}_{5 \%} \\
(3)\end{array}$} & \multirow{2}{*}{$\begin{array}{c}\text { Átlag } \\
(4)\end{array}$} \\
\hline & 0 & 1 & 2 & 3 & & \\
\hline N kg/ha/év (5) & 0 & 100 & 200 & 300 & - & 150 \\
\hline N kg/ha/32 év (6) & 0 & 3200 & 6400 & 9600 & - & 4800 \\
\hline $\mathrm{P}_{2} \mathrm{O}_{5} \mathrm{~kg} / \mathrm{ha} / 32$ év (7) & 0 & 1500 & 3000 & 4500 & - & 2250 \\
\hline $\mathrm{K}_{2} \mathrm{O}$ kg/ha/32 év (8) & 0 & 2500 & 5000 & 7500 & - & 3750 \\
\hline $\mathrm{AL}-\mathrm{P}_{2} \mathrm{O}_{5} \mathrm{mg} / \mathrm{kg}(9)$ & 87 & 214 & 444 & 704 & 56 & 362 \\
\hline $\mathrm{AL}-\mathrm{K}_{2} \mathrm{O} \mathrm{mg} / \mathrm{kg}(10)$ & 158 & 201 & 279 & 363 & 39 & 250 \\
\hline
\end{tabular}

Table 1. Treatments and their effects on the soluble PK-content in the plow layer. (Calcareous loamy chernozem, Nagyhörcsök, Mezőföld region). (1) Fertilisation and soil analysis, (2) Treatments or fertilisation levels, (3) $\mathrm{LSD}_{5 \%}$, (4) Mean, (5) $\mathrm{N} \mathrm{kg} \mathrm{ha}^{-1}$ years ${ }^{-1}$, (6) $\mathrm{N} \mathrm{kg} \mathrm{ha}^{-1} 32$ years-1, (7) $\mathrm{P}_{2} \mathrm{O}_{5} \mathrm{~kg} \mathrm{ha}^{-1}$

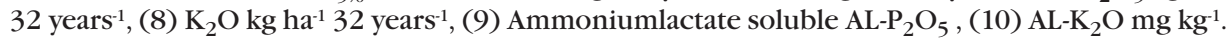

Kaszálásonként és parcellánként bonitáltuk a növényállomány fejlettségét, borítottságát, magasságát. Az egyes komponensek változását dr. Szemán László (SZIE Gödöllő) és dr. Vinczeffy Imre (DE Debrecen), a gyomosodást dr. Radics László (KÉE Budapest), a minőségvizsgálatokat dr. Győri Zoltán (DE Debrecen) végezte. A telepítés elốtt talajmintákat vettünk a szántott rétegből parcellánként 20-20 pontminta/lefúrás egyesítésével. A mintákban meghatároztuk a NH 4 -acetát+EDTA-oldható makro- és mikroelemeket Lakanen és Erviö (1971), valamint az $\mathrm{NH}_{4}$-laktát-oldható PK tartalmat Egnér et al. (1960) szerint.

Csapadékellátottság. A vizsgált 2007. évben januárban 18, februárban 38, márciusban 36, áprilisban 0, májusban a kaszálásig még $85 \mathrm{~mm}$ esô hullott a telepen. A közel 5 hónap alatt mindössze $177 \mathrm{~mm}$. Ezt követôen a június $45 \mathrm{~mm}$, 
július 22 mm csapadékot hozott. A gyep elszáradt, 2. kaszálásra már nem került sor. Augusztus ugyan esốs volt $97 \mathrm{~mm}$ hozammal, de a gyep már nem indult fejlődésnek. A talaj vízkészlete sem töltődött fel az előző évi nyugalmi időszak alatt. 2006-ban a 2. kaszálás szeptemberben történt, utána októberben $21 \mathrm{~mm}$, novemberben $14 \mathrm{~mm}$, decemberben $5 \mathrm{~mm}$ esố hullott.

2. táblázat. Növényi sorrend a kísérletben 1974-2007 között

(Karbonátos csernozjom vályogtalaj, Nagyhörcsök, Mezóföld)

\begin{tabular}{rclccl}
\hline $\mathrm{N}^{\circ}$ & $\begin{array}{c}\text { Évek } \\
(1)\end{array}$ & $\begin{array}{c}\text { Kísérleti növény } \\
(2)\end{array}$ & $\mathrm{N}^{\circ}$ & $\begin{array}{c}\text { Évek } \\
(1)\end{array}$ & $\begin{array}{c}\text { Kísérleti növény } \\
(2)\end{array}$ \\
\hline 1. & 1974 & Búza (3) & 18. & 1991 & Tritikále (18) \\
2. & 1975 & Búza (3) & 19. & 1992 & Cirok (19) \\
3. & 1976 & Kukorica (4) & 20. & 1993 & Silókukorica (20) \\
4. & 1977 & Kukorica (4) & 21. & 1994 & Sárgarépa (21) \\
5. & 1978 & Burgonya (5) & 22. & 1995 & Rozs (22) \\
6. & 1979 & Ószi árpa (6) & 23. & 1996 & Köles (23) \\
7. & 1980 & Zab (7) & 24. & 1997 & Bab (24) \\
8. & 1981 & Cukorrépa (8) & 25. & 1998 & Olaszperje (25) \\
9. & 1982 & Napraforgó (9) & 26. & 1999 & Olaszperje (25) \\
10. & 1983 & Mák (10) & 27. & 2000 & Spenót (26) \\
11. & 1984 & Repce (11) & 28. & 2001 & Gyep (27) \\
12. & 1985 & Mustár (12) & 29. & 2002 & Gyep (27) \\
13. & 1986 & Sörárpa (13) & 30. & 2003 & Gyep (27) \\
14. & 1987 & Olajlen (14) & 31. & 2004 & Gyep (27) \\
15. & 1988 & Szója (15) & 32. & 2005 & Gyep (27) \\
16. & 1989 & Rostkender (16) & 33. & 2006 & Gyep (27) \\
17. & 1990 & Borsó (17) & 34. & 2007 & Gyep (27) \\
\hline
\end{tabular}

Table 2. Crop sequence in the experiment, 1974-2003. (Calcareous loamy chernozem, Nagyhörcsök, Mezőföld region). (1) Years, (2) Crop species, (3) Winter wheat, (4) Maize, (5) Potato, (6) Winter barley, (7) Oat, (8) Sugarbeet, (9) Sunflower, (10) Poppy, (11) Rapeseed, (12) Mustard, (13) Spring barley, (14) Oilflax, (15) Soybean, (16) Flax, (17) Pea, (18) Triticale, (19) Sorghum, (20) Fodder maize, (21) Carrot, (22) Rye, (23) Millet, (24) Bean, (25) Italian ryegrass, (26) Spinach, (27) Grasses. 
3. táblázat. A kisérletben elvetett fümagkeverék összetétele

\begin{tabular}{clcc}
\hline N & \multicolumn{1}{c}{$\begin{array}{c}\text { Komponensek } \\
\text { (1) }\end{array}$} & $\begin{array}{c}\mathrm{kg} / \mathrm{ha} \\
(2)\end{array}$ & $\begin{array}{c}\% \\
(3)\end{array}$ \\
\hline 1. & Réti csenkesz (Festuca pratensis) (5) & 15,0 & 25 \\
2. & Nádképú csenkesz (Festuca arundinacea) (6) & 12,6 & 21 \\
3. & Angol perje (Lolium perenne) (7) & 12,6 & 21 \\
4. & Taréjos búzafú (Agropyron cristatum) (8) & 5,4 & 9 \\
5. & Vörös csenkesz (Festuca rubra) (9) & 3,6 & 6 \\
6. & Réti komócsin (Phleum pratense) (10) & 3,6 & 6 \\
7. & Zöld pántlikafú (Phalaris arundinacea) (11) & 3,6 & 6 \\
8. & Csomós ebir (Dactylis glomerata) (12) & 3,6 & 6 \\
& Összesen (4) & 60,0 & 100 \\
\hline
\end{tabular}

Table 3. Seed mixture of sown grass species. (1) Components, (2) $\mathrm{kg} \mathrm{ha}^{-1}$, (3) \%, (4) Total, (5) Meadow fescue, (6) Tall fescue, (7) Perennial ryegrass, (8) Agropyron, (9) Red fescue, (10) Timothy, (11) Reed canarygrass, (12) Cocksfoot.

\section{Eredmények értékelése}

Bonitálásaink szerint a N-nélküli parcellákon a gyep igen gyengén fejlett, ritka, alacsony és sárga színú, míg a N-nel és P-ral egyaránt jól ellátott talajon jól fejlett, magas, sûrú és sötétzöld színú volt. A 34 éve trágyázásban nem részesített NP-kontroll kezelésben 0,5 t/ha, a maximális NP-ellátottságon 4,0 t/ha szénatermés képződött. Önmagában a P-trágyázás nem növelte a termést a N-hiányos talajon. A N-trágyázás viszont P-hiányos talajon csak a $100 \mathrm{~kg} / \mathrm{ha} / \mathrm{év}$ adagig volt hatékony, a kontroll parcella hozamát közel megnégyszerezve. A bőséges nitrogén és foszfor együttes trágyázással viszont a kontroll termése 8-szorosára nőtt. Az emelkedő K-szintek érdemi terméstöbbleteket nem okoztak ezen a K-mal közepesen ellátott termőhelyen.

A fú légszárazanyaga 30\% körüli volt átlagosan, melyet a P-trágyázás 1,8\%kal igazolhatóan növelt, serkentve a gyep elöregedését. Az 1 kg felhasznált N-re jutó szénatöbblet 5-22 kg között változott az N és P ellátottság függvényében. A növekvő $\mathrm{N}$-adaggal természetszerúen a hatékonyság csökkent, hiszen a Nhatás nem lineáris, míg a javuló P-kínálat megkétszerezte a nagyobb N-adagok által okozott terméstöbbleteket. Kedvezónek tekintjük a N-hatékonyságot, ha 20-25 kg szénatöbblettel jár minden kg N felhasználása. Megállapíthatjuk, hogy ebben a száraz évben, mely egy kaszálást adott, csak a 100 kg/ha/év N-adag bizonyult hatékonynak a P-ral is kielégítôen ellátott talajon (4. táblázat). 
4. táblázat. $N$ és P ellátottsági szintek hatása a légszáraz gyepszéna fejlódésére, termésére és a N-adagok fajlagos hatékonyságára 2007. 05. 22-én (Mészlepedékes csernozjom vályogtalaj, Nagyhörcsök, Mezöföld)

\begin{tabular}{|c|c|c|c|c|c|c|}
\hline \multirow{2}{*}{$\begin{array}{l}\mathrm{AL}-\mathrm{P}_{2} \mathrm{O}_{5} \\
\mathrm{mg} / \mathrm{kg}\end{array}$} & \multicolumn{4}{|c|}{$\begin{array}{c}\text { N-trágyázás, } \mathrm{N} \mathrm{kg/ha/év} \\
\text { (1) }\end{array}$} & \multirow{2}{*}{$\begin{array}{l}\mathrm{SzD}_{5 \%} \\
(2)\end{array}$} & \multirow{2}{*}{$\begin{array}{c}\text { Átlag } \\
(3)\end{array}$} \\
\hline & 0 & 100 & 200 & 300 & & \\
\hline \multicolumn{7}{|c|}{ Bonitálás ( 1 = igen gyengén, 5 = jól fejlett állomány) (4) } \\
\hline 87 & 1,0 & 3,6 & 3,6 & 3,8 & & 3,0 \\
\hline 214 & 1,0 & 3,4 & 4,2 & 4,5 & 0,5 & 3,3 \\
\hline 444 & 1,0 & 3,5 & 4,3 & 4,5 & & 3,3 \\
\hline 704 & 1,0 & 3,8 & 4,6 & 4,9 & & 3,6 \\
\hline Átlag (3) & 1,0 & 3,6 & 4,2 & 4,4 & 0,3 & 3,3 \\
\hline \multicolumn{7}{|c|}{ Légszáraz széna, t/ha (5) } \\
\hline 87 & 0,5 & 1,9 & 2,1 & 2,1 & & 1,7 \\
\hline 214 & 0,5 & 2,4 & 3,1 & 3,5 & 0,4 & 2,4 \\
\hline 444 & 0,6 & 2,8 & 3,5 & 3,9 & & 2,7 \\
\hline 704 & 0,5 & 2,6 & 3,8 & 4,0 & & 2,7 \\
\hline Átlag (3) & 0,5 & 2,4 & 3,1 & 3,4 & 0,2 & 2,4 \\
\hline \multicolumn{7}{|c|}{ Többlet széna kg/1 kg N-re (6) } \\
\hline 87 & - & 14 & 8 & 5 & & 9 \\
\hline 214 & - & 19 & 13 & 10 & 4 & 14 \\
\hline 444 & - & 22 & 14 & 11 & & 16 \\
\hline 704 & - & 21 & 16 & 12 & & 16 \\
\hline Átlag (3) & - & 19 & 13 & 10 & 2 & 14 \\
\hline
\end{tabular}

Megjegyzés: az igen gyengén fejlett állomány ritka, alacsony és sárga színú, míg a jól fejlett állomány magas, súrú és haragos zöld színú volt. A légszáraz anyag 34\%-ot tett ki átlagosan.

Table 4. The effect of $\mathrm{N}$ and $\mathrm{P}$ levels of supply on the development and yield of air-dry grass hay, as well as the specific effectivity of $\mathrm{N}$ dosages on 22/05/2007 (Calcareous loamy chernozem, Nagyhörcsök, Mezőföld region). (1) N-fertilisation $\mathrm{N} \mathrm{kg} \mathrm{ha}^{-1}$ year-1, (2) LSD ${ }_{5 \%}$, (3) Mean, (4) Classification ( $1=$ weakly developed population, $5=$ well developed population), (5) Air-dry hay, $\mathrm{t} \mathrm{ha}^{-1}$, (6) Extra hay kg per kg N. Note: the weakly developed popluation is sparse, low and yellow, while the well developed population is dense, high and fierce green. The average ratio of air-dry material was $34 \%$.

Mútrágyázás hatását a légszáraz gyepszéna elemösszetételére az 5. táblázatban tanulmányozhatjuk. Döntően itt is a N-hatások kifejezettebbek. A nagyobb terméstömeggel fellépó hígulás nyomán mérséklôdött a K, P és a $\mathrm{S}$ a szénában. A Mo-tartalom erôteljesebb csökkenéséhez a nitrát és molibdenát közötti anion- 
antagonizmus is hozzájárulhatott. Az egyéb vizsgált elemek koncentrációi emelkedtek. Érvényesült a N általános „hajtó” hatása.

5. táblázat. Mútrágyázás hatása a gyepszéna összetételére 2007. 05. 22-én (Mészlepedékes csernozjom vályogtalaj, Nagyhörcsök, Mezöföld)

\begin{tabular}{|c|c|c|c|c|c|c|c|}
\hline \multirow{2}{*}{$\begin{array}{c}\text { Elem } \\
\text { jele } \\
(1)\end{array}$} & \multirow{2}{*}{$\begin{array}{l}\text { Mérték- } \\
\text { egység } \\
\text { (2) }\end{array}$} & \multicolumn{4}{|c|}{$\begin{array}{c}\text { N-trágyázás, N kg/ha/év } \\
\text { (3) }\end{array}$} & \multirow{2}{*}{$\begin{array}{l}\mathrm{SZD}_{5 \%} \\
(4)\end{array}$} & \multirow{2}{*}{$\begin{array}{l}\text { Átlag } \\
\text { (5) }\end{array}$} \\
\hline & & 0 & 100 & 200 & 300 & & \\
\hline $\mathbf{N}$ & $\%$ & 0,95 & 1,45 & 2,05 & 2,30 & 0,11 & 1,68 \\
\hline K & $\%$ & 1,73 & 1,66 & 1,43 & 1,51 & 0,19 & 1,58 \\
\hline $\mathrm{Ca}$ & $\%$ & 0,43 & 0,55 & 0,61 & 0,63 & 0,06 & 0,55 \\
\hline $\mathrm{P}$ & $\%$ & 0,35 & 0,24 & 0,22 & 0,22 & 0,03 & 0,26 \\
\hline $\mathrm{Mg}$ & $\%$ & 0,17 & 0,20 & 0,20 & 0,19 & 0,02 & 0,19 \\
\hline$S$ & $\%$ & 0,22 & 0,14 & 0,15 & 0,17 & 0,02 & 0,17 \\
\hline $\mathrm{NO}_{3}-\mathrm{N}$ & $\mathrm{g} / \mathrm{kg}$ & 0,18 & 0,38 & 1,66 & 2,00 & 0,22 & 1,05 \\
\hline $\mathrm{Na}$ & $\mathrm{g} / \mathrm{kg}$ & 0,15 & 0,74 & 1,02 & 0,57 & 0,22 & 0,62 \\
\hline $\mathrm{Fe}$ & $\mathrm{mg} / \mathrm{kg}$ & 61 & 72 & 86 & 91 & 10 & 78 \\
\hline Mn & $\mathrm{mg} / \mathrm{kg}$ & 49 & 69 & 76 & 85 & 8 & 70 \\
\hline $\mathrm{Al}$ & $\mathrm{mg} / \mathrm{kg}$ & 33 & 36 & 44 & 45 & 9 & 40 \\
\hline $\mathrm{Zn}$ & $\mathrm{mg} / \mathrm{kg}$ & 12 & 16 & 20 & 21 & 2 & 17 \\
\hline $\mathrm{Sr}$ & $\mathrm{mg} / \mathrm{kg}$ & 13 & 16 & 17 & 19 & 2 & 16 \\
\hline B & $\mathrm{mg} / \mathrm{kg}$ & 4,2 & 5,2 & 5,3 & 5,2 & 0,5 & 5,0 \\
\hline $\mathrm{Cu}$ & $\mathrm{mg} / \mathrm{kg}$ & 2,3 & 3,4 & 4,2 & 4,6 & 0,3 & 3,6 \\
\hline $\mathrm{Ba}$ & $\mathrm{mg} / \mathrm{kg}$ & 2,3 & 2,4 & 3,2 & 4,1 & 0,6 & 3,0 \\
\hline Mo & $\mathrm{mg} / \mathrm{kg}$ & 1,2 & 1,5 & 0,8 & 0,7 & 0,2 & 1,0 \\
\hline \multirow{2}{*}{$\begin{array}{c}\text { Elem } \\
\text { jele } \\
(1)\end{array}$} & \multirow{2}{*}{$\begin{array}{l}\text { Mérték- } \\
\text { egység } \\
\text { (2) }\end{array}$} & \multicolumn{4}{|c|}{$\begin{array}{c}\text { AL- } \mathrm{P}_{2} \mathrm{O}_{5}, \mathrm{mg} / \mathrm{kg} \text { a szántott rétegben } \\
(6)\end{array}$} & \multirow{2}{*}{$\begin{array}{l}\mathrm{SZD}_{5 \%} \\
(4)\end{array}$} & \multirow{2}{*}{$\begin{array}{l}\text { Átlą } \\
(5)\end{array}$} \\
\hline & & 87 & 214 & 444 & 704 & & \\
\hline$P$ & $\%$ & 0,17 & 0,26 & 0,28 & 0,31 & 0,03 & 0,26 \\
\hline$S$ & $\%$ & 0,15 & 0,16 & 0,18 & 0,19 & 0,02 & 0,17 \\
\hline $\mathrm{Zn}$ & $\mathrm{mg} / \mathrm{kg}$ & 19 & 17 & 17 & 16 & 2 & 17 \\
\hline $\mathrm{Sr}$ & $\mathrm{mg} / \mathrm{kg}$ & 11 & 16 & 18 & 21 & 2 & 16 \\
\hline Mo & $\mathrm{mg} / \mathrm{kg}$ & 1,4 & 1,1 & 0,8 & 0,9 & 0,2 & 1,0 \\
\hline
\end{tabular}

Az 5. táblázat folytatása a következó oldalon... 
KÁDÁR I.-RAGÁLYI P.

Az 5. táblázat folytatása ...

\begin{tabular}{lccccccc}
\hline \multirow{2}{*}{$\begin{array}{c}\text { Elem } \\
\text { jele }\end{array}$} & $\begin{array}{c}\text { Mérték- } \\
\text { egység }\end{array}$ & \multicolumn{9}{c}{$\begin{array}{c}\text { AL-K2O, mg/kg a szántott rétegben } \\
(7)\end{array}$} & $(2)$ & 158 & 201 & 279 & 363 & SZD $_{5 \%}$ & Átlag \\
\cline { 3 - 6 } & $\%$ & 1,18 & 1,40 & 1,73 & 2,02 & 0,19 & $(5)$ \\
\hline $\mathrm{K}$ & $\%$ & 0,66 & 0,59 & 0,48 & 0,49 & 0,06 & 0,55 \\
$\mathrm{Ca}$ & $\%$ & 0,22 & 0,20 & 0,17 & 0,17 & 0,02 & 0,19 \\
$\mathrm{Mg}$ & $\mathrm{g} / \mathrm{kg}$ & 0,88 & 0,86 & 0,43 & 0,30 & 0,22 & 0,62 \\
$\mathrm{Na}$ & $\mathrm{mg} / \mathrm{kg}$ & 19 & 17 & 15 & 15 & 2 & 16 \\
$\mathrm{Sr}$ & $\mathrm{mg} / \mathrm{kg}$ & 5,6 & 4,8 & 4,7 & 4,7 & 0,5 & 5,0 \\
$\mathrm{~B}$ & $\mathrm{mg} / \mathrm{kg}$ & 3,9 & 3,7 & 3,4 & 3,4 & 0,3 & 3,6 \\
$\mathrm{Cu}$ & & &
\end{tabular}

Megjegyzés: Se 0,6; Cr és Hg 0,1; Co 0,04 mg/kg kimutatási határ alatt.

Table 5. The effect of fertilisation on the composition of grass hay on 22/05/2007 (Calcareous loamy chernozem, Nagyhörcsök, Mezőföld region). (1) Element, (2) Measurement unit, (3) N fertilisation, $\mathrm{kg} \mathrm{ha}^{-1}$ year-1, (4) $\mathrm{LSD}_{5 \%}$, (5) Mean, (6) $\mathrm{AL}_{-} \mathrm{P}_{2} \mathrm{O}_{5}, \mathrm{mg} \mathrm{kg}^{-1}$ in the ploughed layer, (7) AL$\mathrm{K}_{2} \mathrm{O}$, $\mathrm{mg} \mathrm{kg}^{-1}$ in the ploughed layer. Note: Se 0.6; Cr and $\mathrm{Hg} \mathrm{0.1;} \mathrm{Co} 0.04 \mathrm{mg} \mathrm{kg}^{-1}$ were under the detection level.

Kérdés, hogy ezek a változások mennyiben minősíthetôk kedvezőnek, vagy nemkívánatosnak takarmányozási szempontból. Irodalmi adatok szerint a tejelố tehenek számára megfelelô, szárazanyagra számítva a 2-3\% N; 1-2\% K; 0,5-0,7\% Ca; 0,2-0,4\% P; 0,1-0,2\% Mg Na, illetve 50-160 mg/kg Fe és Mn; 30$50 \mathrm{mg} / \mathrm{kg} \mathrm{Zn;} \mathrm{8-10} \mathrm{mg/kg} \mathrm{Cu;} \mathrm{5-8} \mathrm{mg/kg} \mathrm{B;} \mathrm{0,1-0,5} \mathrm{mg/kg} \mathrm{Mo,} \mathrm{Se} \mathrm{és} \mathrm{Co} \mathrm{össze-}$ tételú takarmány (Horváth és Prohászka 1976, Finck 1982, Whitehead 1970). Az állatok sóigényét közismerten csak a szikes gyepek emelkedett $\mathrm{NaCl}$ tartalma képes kielégíteni.

A növekvő P-kínálattal megemelkedik a P és a S \%-a, a Sr mennyisége, valamint csökken a Zn és a Mo koncentrációja. A szuperfoszfát P-és S-forrásul is szolgál, emellett 1-2\% Sr-ot is tartalmaz szennyezésként korábbi elemzéseink szerint (Kádár 1992). Ismert ugyanakkor a P-Zn, illetve a foszfát-molibdenát antagonizmus a növényi felvételben. Az említett elemek tartalmában mért változások tehát magyarázhatók. A K-kínálattal csak a széna K-tartalma nôtt. Az egyéb elemek mennyisége visszaesett a kationangatonizmus, illetve a K-B antagonizmus eredményeképpen. Legkifejezettebben a Na elemé. Annak ellenére, hogy a kálisó 5-10\% Na-ot is tartalmazhat (5. táblázat).

Lássuk, milyen mérvú módosulásokat okozhat az együttes nitrogén és foszfor bôsége a légszáraz gyepszéna elemtartalmában. A 6. táblázat adatai szerint 
a P 0,14-0,40\%, S 0,13-0,23\%, Zn 12-23 mg/kg, Sr 10-24 mg/kg, Mo 0,5-2,3 $\mathrm{mg} / \mathrm{kg}$ szélsó értékek szerint változott. $\mathrm{A} \mathrm{NO}_{3}-\mathrm{N}$ tartaléktápanyagnak minôsül.

6. táblázat. $N$ és P ellátottsági szintek hatása a légszáraz gyepszéna elemtartalmára 2007. 05. 22-én a K-kezelések átlagában

(Mészlepedékes csernozjom vályogtalaj, Nagyhörcsök, Mezöföld)

\begin{tabular}{|c|c|c|c|c|c|c|}
\hline \multirow{2}{*}{$\begin{array}{l}\mathrm{AL}-\mathrm{P}_{2} \mathrm{O}_{5} \\
(\mathrm{mg} / \mathrm{kg})\end{array}$} & \multicolumn{4}{|c|}{$\begin{array}{c}\text { N-trágyázás, } \mathrm{N} \text { kg/ha/év } \\
\text { (1) }\end{array}$} & \multirow{2}{*}{$\begin{array}{l}\mathrm{SzD}_{5 \%} \\
(2)\end{array}$} & \multirow{2}{*}{$\begin{array}{l}\text { Átlag } \\
(3)\end{array}$} \\
\hline & 0 & 100 & 200 & 300 & & \\
\hline \multicolumn{7}{|c|}{ P (\%) } \\
\hline 87 & 0,29 & 0,11 & 0,14 & 0,14 & & 0,17 \\
\hline 214 & 0,36 & 0,25 & 0,23 & 0,21 & 0,04 & 0,26 \\
\hline 444 & 0,33 & 0,28 & 0,26 & 0,26 & & 0,28 \\
\hline 704 & 0,40 & 0,31 & 0,25 & 0,28 & & 0,31 \\
\hline Átlag (3) & 0,35 & 0,24 & 0,22 & 0,22 & 0,02 & 0,26 \\
\hline \multicolumn{7}{|c|}{ S (\%) } \\
\hline 87 & 0,22 & 0,12 & 0,13 & 0,13 & & 0,15 \\
\hline 214 & 0,21 & 0,13 & 0,14 & 0,15 & 0,04 & 0,16 \\
\hline 444 & 0,20 & 0,15 & 0,17 & 0,19 & & 0,18 \\
\hline 704 & 0,23 & 0,16 & 0,17 & 0,21 & & 0,19 \\
\hline Átlag (3) & 0,22 & 0,14 & 0,15 & 0,17 & 0,02 & 0,17 \\
\hline \multicolumn{7}{|c|}{ Zn (\%) } \\
\hline 87 & 13 & 19 & 22 & 23 & & 19 \\
\hline 214 & 12 & 16 & 20 & 18 & 4 & 17 \\
\hline 444 & 10 & 14 & 21 & 23 & & 17 \\
\hline 704 & 12 & 15 & 16 & 20 & & 16 \\
\hline Átlag (3) & 12 & 16 & 20 & 21 & 2 & 17 \\
\hline \multicolumn{7}{|c|}{$\mathrm{Sr}(\mathrm{mg} / \mathrm{kg})$} \\
\hline 87 & 10 & 10 & 12 & 12 & & 11 \\
\hline 214 & 12 & 16 & 16 & 18 & 4 & 16 \\
\hline 444 & 13 & 18 & 20 & 21 & & 18 \\
\hline 704 & 18 & 21 & 21 & 24 & & 21 \\
\hline Átlag (3) & 13 & 16 & 17 & 19 & 2 & 16 \\
\hline
\end{tabular}

A 6. táblázat folytatása a következô oldalon... 
KÁDÁR I.-RAGÁLYI P.

A 6. táblázat folytatása...

\begin{tabular}{|c|c|c|c|c|c|c|}
\hline \multirow{2}{*}{$\begin{array}{l}\mathrm{AL}-\mathrm{P}_{2} \mathrm{O}_{5} \\
(\mathrm{mg} / \mathrm{kg})\end{array}$} & \multicolumn{4}{|c|}{$\begin{array}{c}\text { N-trágyázás, } \mathrm{N} \mathrm{kg/ha/év} \\
\text { (1) }\end{array}$} & \multirow{2}{*}{$\begin{array}{l}\mathrm{SzD}_{5 \%} \\
(2)\end{array}$} & \multirow{2}{*}{$\begin{array}{c}\text { Átlag } \\
\text { (3) }\end{array}$} \\
\hline & 0 & 100 & 200 & 300 & & \\
\hline \multicolumn{7}{|c|}{ Mo $(\mathrm{mg} / \mathrm{kg})$} \\
\hline 87 & 1,2 & 2,3 & 1,3 & 1,0 & & 1,4 \\
\hline 214 & 1,2 & 1,5 & 0,9 & 0,7 & 0,4 & 1,1 \\
\hline 444 & 1,0 & 1,1 & 0,7 & 0,5 & & 0,8 \\
\hline 704 & 1,3 & 1,2 & 0,5 & 0,5 & & 0,9 \\
\hline Átlag (3) & 1,2 & 1,5 & 0,8 & 0,7 & 0,2 & 1,0 \\
\hline \multicolumn{7}{|c|}{$\mathrm{NO}_{3}-\mathrm{N}(\mathrm{g} / \mathrm{kg})$} \\
\hline 87 & 0,18 & 0,75 & 2,34 & 3,15 & & 1,61 \\
\hline 214 & 0,18 & 0,37 & 1,74 & 2,24 & 0,44 & 1,13 \\
\hline 444 & 0,18 & 0,28 & 1,47 & 1,21 & & 0,78 \\
\hline 704 & 0,17 & 0,12 & 1,08 & 1,40 & & 0,69 \\
\hline Átlag (3) & 0,18 & 0,38 & 1,66 & 2,00 & 0,22 & 1,05 \\
\hline
\end{tabular}

Table 6 . The effect of $\mathrm{N}$ and $\mathrm{P}$ supply levels on the element content of air-dry grass hay on $22 / 05 / 2007$ in the average of $\mathrm{K}$ treatments (Calcareous loamy chernozem, Nagyhörcsök, Mezóföld region). (1) N fertilisation, $\mathrm{kg} \mathrm{ha}^{-1} \mathrm{year}^{-1}$, (2) $\mathrm{LSD}_{5 \%}$, (3) Mean.

A N-kontroll talajon kereken 0,2 g/kg vagy ezrelék, míg a N-túlsúlyos, de Phiányos kezelésben 3,2 g/kg koncentrációt mértünk. A zöld növények általában 8-10 körüli N/P arányt igényelnek fejlődésükhöz. Amennyiben az egyik elem hiányzik, a másik elem beépülése is gátolt. Az össz-N 15\%-át találjuk $\mathrm{NO}_{3}$ formában pl. az $\mathrm{N}_{3} \mathrm{P}_{0}, 12 \%$-át az $\mathrm{N}_{3} \mathrm{P}_{1}, 5 \%$-át az $\mathrm{N}_{3} \mathrm{P}_{2}$ és mindössze $2 \%$-át az $\mathrm{N}_{3} \mathrm{P}_{3}$ kezelésben. Az utóbbi kezelésben mindkét fó tápelem egyaránt és bőségben áll rendelkezésre, az N/P aránya 8,6 volt.

Az N és K elemek közötti kölcsönhatások nem kevésbé fontosak. A 7. táblázatban közölt eredmények szerint a K kereken 1,1-2,2\%, Ca 0,4-0,8\%, Na 0,1-1,5 g/kg, Sr 12-22 mg/kg, B 4-6 mg/kg körüli tartományban változik extrém értékeket tekintve. Különös figyelmet érdemel a talaj-növény rendszerben rendkívüli mobilis Na viselkedése. A N-trágyázással a széna Na-készlete nagyságrenddel megnôhet. A N mútrágya gyakorlatilag nem tartalmaz Na elemet. A kálisó igen. Mégis, az emelkedő K-kínálattal a széna K-tartalma átlagosan 1/3-ára süllyed. A jelenségre nem tudunk logikus magyarázattal szolgálni. 
Mútrágyahatások vizsgálata 7. éves...

7. táblázat. $N$ és K tápláltsági szintek hatása a légszáraz gyep elemtartalmára 2007. 05. 22-én a kezelések átlagában

(Mészlepedékes csernozjom vályogtalaj, Nagyhörcsök, Mezöföld)

\begin{tabular}{|c|c|c|c|c|c|c|}
\hline \multirow{2}{*}{$\begin{array}{l}\mathrm{AL}-\mathrm{K}_{2} \mathrm{O} \\
(\mathrm{mg} / \mathrm{kg})\end{array}$} & \multicolumn{4}{|c|}{$\begin{array}{c}\text { N-trágyázás, } \mathrm{N} \text { kg/ha/év } \\
\text { (1) }\end{array}$} & \multirow{2}{*}{$\begin{array}{l}\mathrm{SzD}_{5 \%} \\
(2)\end{array}$} & \multirow{2}{*}{$\begin{array}{l}\text { Átlag } \\
\text { (3) }\end{array}$} \\
\hline & 0 & 100 & 200 & 300 & & \\
\hline \multicolumn{7}{|c|}{ K (\%) } \\
\hline 158 & 1,64 & 1,15 & 0,87 & 1,07 & & 1,18 \\
\hline 201 & 1,70 & 1,50 & 1,24 & 1,17 & 0,38 & 1,40 \\
\hline 279 & 1,77 & 1,94 & 1,67 & 1,55 & & 1,73 \\
\hline 363 & 1,80 & 2,08 & 1,96 & 2,24 & & 2,02 \\
\hline Átlag (3) & 1,73 & 1,66 & 1,43 & 1,51 & 0,19 & 1,58 \\
\hline \multicolumn{7}{|c|}{$\mathrm{Ca}(\%)$} \\
\hline 158 & 0,47 & 0,64 & 0,80 & 0,76 & & 0,66 \\
\hline 201 & 0,39 & 0,66 & 0,65 & 0,65 & 0,12 & 0,59 \\
\hline 279 & 0,41 & 0,47 & 0,48 & 0,55 & & 0,48 \\
\hline 363 & 0,44 & 0,44 & 0,51 & 0,56 & & 0,49 \\
\hline Átlag (3) & 0,43 & 0,55 & 0,61 & 0,63 & 0,06 & 0,55 \\
\hline \multicolumn{7}{|c|}{$\mathrm{Na}(\mathrm{g} / \mathrm{kg})$} \\
\hline 158 & 0,23 & 1,28 & 1,22 & 0,80 & & 0,88 \\
\hline 201 & 0,11 & 1,09 & 1,49 & 0,77 & 0,44 & 0,86 \\
\hline 279 & 0,14 & 0,41 & 0,84 & 0,32 & & 0,43 \\
\hline 363 & 0,11 & 0,17 & 0,54 & 0,38 & & 0,30 \\
\hline Átlag (3) & 0,15 & 0,74 & 1,02 & 0,57 & 0,22 & 0,62 \\
\hline \multicolumn{7}{|c|}{$\mathrm{Sr}(\mathrm{mg} / \mathrm{kg})$} \\
\hline 158 & 14 & 18 & 21 & 22 & & 19 \\
\hline 201 & 12 & 19 & 18 & 20 & 4 & 17 \\
\hline 279 & 13 & 14 & 15 & 16 & & 15 \\
\hline 363 & 14 & 13 & 16 & 17 & & 15 \\
\hline Átlag (3) & 13 & 16 & 17 & 19 & 2 & 16 \\
\hline \multicolumn{7}{|c|}{$\mathrm{B}(\mathrm{mg} / \mathrm{kg})$} \\
\hline 158 & 4,4 & 6,1 & 6,7 & 5,4 & & 5,6 \\
\hline 201 & 3,7 & 5,4 & 5,1 & 4,8 & 1,0 & 4,8 \\
\hline 279 & 4,3 & 4,8 & 4,6 & 5,0 & & 4,7 \\
\hline 363 & 4,4 & 4,3 & 5,0 & 5,3 & & 4,7 \\
\hline Átlag (3) & 4,2 & 5,2 & 5,3 & 5,2 & 0,5 & 5,0 \\
\hline
\end{tabular}

Table 7. The effect of $\mathrm{N}$ and $\mathrm{K}$ supply levels on the element content of air-dry grass hay on 22/05/2007 in the average of $\mathrm{K}$ treatments (Calcareous loamy chernozem, Nagyhörcsök, Mezőföld region). (1) $\mathrm{N}$ fertilisation, $\mathrm{kg} \mathrm{ha}^{-1}$ year ${ }^{-1},(2) \mathrm{LSD}_{5 \%}$, (3) Mean. 
A 8. táblázat eredményei érzékeltetik néhány tápelemarány változásának irányát és mértékét az $\mathrm{N}$ és $\mathrm{P}$ ellátottság függvényében. Amint látható, az N/P aránya kereken 2-15, a Cu/Mo aránya 2-10, a P/ $\mathrm{NO}_{3}-\mathrm{N}$ aránya 20-200, a P/Zn aránya 60-330 közötti értékeket mutatta. Amint korábban említettük, az optimális N/P aránya a fiatal zöld növényi szövetekben általában 8-12 közötti.

A terméssel felvett elemek mennyiségeit tájékoztató jelleggel a 9. táblázat foglalja össze az N és P tápláltság függvényében. A trágyázatlan kontroll és a bőséges NP-kínálat között általában nagyságrendi különbségek adódnak. A kivont N 5-96 kg, Ca 2-26 kg, P 2-11 kg ( $\left.\mathrm{P}_{2} \mathrm{O}_{5} 4-25 \mathrm{~kg}\right), \mathrm{Mg} 1-7 \mathrm{~kg}, \mathrm{~S} 1-8 \mathrm{~kg}$, $\mathrm{NO}_{3}-\mathrm{N}$ 0,1-8,0 kg között változott. A vizsgált mikroelemek tekintetében hasonló mérvú eltéréseket tapasztaltunk. Így pl. a Fe 34-405, Mn 25-354, Al 18-210, Sr 5-95, Zn 7-89, B 2-20, Ba és Cu 1-15, a Mo 0,7-4,0, a Ni 0,1-1,4, a Cd 0,01-0,11 g/ha felvételt jelzett az $\mathrm{N}$ és P ellátottság függvényében. Az As, $\mathrm{Hg}$, Cr, Se, Co felvétele g/ha kimutatási határ alatt maradt.

A K, Na és Mo felvételének extrémebb változásait az itt nem közölt $\mathrm{N}$ és $\mathrm{K}$ kétirányú táblázat eredményei jellemzik. A K 8-84 kg ( $\mathrm{K}_{2} \mathrm{O} 10-100$ kg), Na 0,1-4,9 kg/ha, Mo 0,7-3,7 g/ha szélsố értékeket mutatta. A K-felvétel maximuma az $\mathrm{N}_{3} \mathrm{P}_{3}$-szinthez, a Na felvételi maximuma az $\mathrm{N}_{2} \mathrm{P}_{1}$-szinthez, a Mo felvételi maximuma pedig az $\mathrm{N}_{1} \mathrm{P}_{1}$-szinthez kötődik. A N-túlsúlyos kezelésben ugyanis a Na, illetve a Mo szénában való készlete drasztikusan visszaesik az 5. táblázatban a korábban bemutatottak szerint.

Ami a széna fajlagos elemtartalmát illeti elmondható, hogy 1 t széna előállításához kísérleti körülményeink között 10-23 kg N, 12-20 kg K (14-24 kg $\mathrm{K}_{2} \mathrm{O}$ ), 4-6 kg Ca (5-8 kg CaO), $2 \mathrm{~kg}$ körüli Mg (3-4 kg MgO), 2-3 kg P (4-7 $\mathrm{kg}_{2} \mathrm{O}_{5}$ ) elemet igényelt a gyep átlagosan, eltekintve az extrém szélsô értékektôl. Adataink iránymutatóul szolgálhatnak a tervezett termés elemigényének számításakor a szaktanácsadásban.

\section{Köszönetnyilvánítás}

A kutatás a 68665 sz. OTKA, valamint a HR-22/2008 sz. pályázatok eredményeként az NKTH és a KPI támogatásával jött létre, mely támogatások forrása a Kutatási és Technológiai Innovációs Alap. 
8. táblázat. $N$ és P ellátottsági szintek hatása a légszáraz gyepszéna néhány elemarányára 2007. 05. 22-én a K-kezelések átlagában (Mészlepedékes csernozjom vályogtalaj, Nagyhörcsök, Mezöföld)

\begin{tabular}{|c|c|c|c|c|c|c|}
\hline \multirow{2}{*}{$\begin{array}{l}\mathrm{AL}-\mathrm{P}_{2} \mathrm{O}_{5} \\
(\mathrm{mg} / \mathrm{kg})\end{array}$} & \multicolumn{4}{|c|}{$\begin{array}{c}\text { N-trágyázás, } \mathrm{N} \mathrm{kg/ha/év} \\
\text { (1) }\end{array}$} & \multirow{2}{*}{$\begin{array}{l}\mathrm{SzD}_{5 \%} \\
(2)\end{array}$} & \multirow{2}{*}{$\begin{array}{l}\text { Átlag } \\
(3)\end{array}$} \\
\hline & 0 & 100 & 200 & 300 & & \\
\hline \multicolumn{7}{|c|}{$\mathrm{N} / \mathrm{P}$} \\
\hline 87 & 3,2 & 14,6 & 14,3 & 14,9 & & 11,8 \\
\hline 214 & 2,6 & 5,8 & 9,0 & 10,6 & 4,4 & 7,0 \\
\hline 444 & 2,8 & 5,0 & 8,1 & 9,4 & & 6,3 \\
\hline 704 & 2,4 & 4,3 & 8,1 & 8,6 & & 5,8 \\
\hline Átlag (3) & 2,8 & 7,4 & 9,9 & 10,9 & 2,2 & 7,7 \\
\hline \multicolumn{7}{|c|}{$\mathrm{P} / \mathrm{Zn}$} \\
\hline 87 & 223 & 58 & 64 & 61 & & 102 \\
\hline 214 & 300 & 156 & 115 & 117 & 64 & 172 \\
\hline 444 & 330 & 200 & 124 & 113 & & 192 \\
\hline 704 & 333 & 207 & 156 & 140 & & 209 \\
\hline Átlag (3) & 296 & 155 & 115 & 108 & 32 & 168 \\
\hline \multicolumn{7}{|c|}{$\mathrm{P} / \mathrm{NO}_{3}-\mathrm{N}$} \\
\hline 87 & 16 & 15 & 60 & 44 & & 34 \\
\hline 214 & 20 & 17 & 132 & 94 & 50 & 66 \\
\hline 444 & 18 & 20 & 170 & 215 & & 106 \\
\hline 704 & 22 & 26 & 231 & 200 & & 120 \\
\hline Átlag (3) & 19 & 20 & 148 & 138 & 25 & 82 \\
\hline \multicolumn{7}{|c|}{$\mathrm{Cu} / \mathrm{Mo}$} \\
\hline 87 & 1,9 & 1,5 & 3,1 & 3,8 & & 2,6 \\
\hline 214 & 2,0 & 2,3 & 4,8 & 6,6 & 0,8 & 3,9 \\
\hline 444 & 2,1 & 2,9 & 6,8 & 10,8 & & 5,6 \\
\hline 704 & 1,9 & 2,9 & 7,8 & 9,5 & & 5,5 \\
\hline Átlag (3) & 2,0 & 2,4 & 5,6 & 7,7 & 0,4 & 4,4 \\
\hline
\end{tabular}

Table 8 . The effect of $\mathrm{N}$ and $\mathrm{P}$ supply levels on certain element proportions of air-dry grass hay on 22/05/2007 in the average of $\mathrm{K}$ treatments (Calcareous loamy chernozem, Nagyhörcsök, Mezőföld region). (1) $\mathrm{N}$ fertilisation, $\mathrm{kg} \mathrm{ha}^{-1}$ year ${ }^{-1}$, (2) $\mathrm{LSD}_{5 \%}$, (3) Mean. 
9. táblázat. $N$ és P ellátottsági szintek hatása a légszáraz gyepszéna néhány elemarányára 2007. 05. 22-én a K-kezelések átlagában (Mészlepedékes csernozjom vályogtalaj, Nagyhörcsök, Mezóföld)

\begin{tabular}{|c|c|c|c|c|c|c|}
\hline \multirow{2}{*}{$\begin{array}{l}\mathrm{AL}-\mathrm{P}_{2} \mathrm{O}_{5} \\
(\mathrm{mg} / \mathrm{kg})\end{array}$} & \multicolumn{4}{|c|}{$\begin{array}{c}\text { N-trágyázás, N kg/ha/év } \\
\text { (1) }\end{array}$} & \multirow{2}{*}{$\begin{array}{l}\mathrm{SzD}_{5 \%} \\
(2)\end{array}$} & \multirow{2}{*}{$\begin{array}{l}\text { Átlag } \\
(3)\end{array}$} \\
\hline & 0 & 100 & 200 & 300 & & \\
\hline \multicolumn{7}{|c|}{$\mathrm{N}(\mathrm{kg} / \mathrm{ha})$} \\
\hline 87 & 5 & 31 & 42 & 45 & & 31 \\
\hline 214 & 5 & 35 & 65 & 79 & 8 & 46 \\
\hline 444 & 5 & 38 & 74 & 96 & & 53 \\
\hline 704 & 5 & 34 & 77 & 96 & & 53 \\
\hline Átlag (3) & 5 & 35 & 64 & 79 & 4 & 46 \\
\hline \multicolumn{7}{|c|}{$\mathrm{Ca}(\mathrm{kg} / \mathrm{ha})$} \\
\hline 87 & 2 & 9 & 12 & 12 & & 9 \\
\hline 214 & 2 & 15 & 19 & 24 & 4 & 15 \\
\hline 444 & 2 & 15 & 24 & 25 & & 16 \\
\hline 704 & 2 & 13 & 21 & 26 & & 16 \\
\hline Átlag (3) & 2 & 13 & 19 & 21 & 2 & 14 \\
\hline \multicolumn{7}{|c|}{$P(\mathrm{~kg} / \mathrm{ha})$} \\
\hline 87 & 1,5 & 2,2 & 2,9 & 3,1 & & 2,4 \\
\hline 214 & 1,9 & 6,1 & 7,2 & 7,4 & 0,8 & 5,6 \\
\hline 444 & 1,9 & 7,6 & 8,9 & 10,1 & & 7,1 \\
\hline 704 & 2,2 & 8,0 & 9,4 & 11,1 & & 7,7 \\
\hline Átlag (3) & 1,9 & 5,9 & 7,1 & 7,7 & 0,4 & 5,7 \\
\hline \multicolumn{7}{|c|}{$\operatorname{Mg}(\mathrm{kg} / \mathrm{ha})$} \\
\hline 87 & 0,9 & 3,7 & 4,8 & 4,7 & & 3,5 \\
\hline 214 & 0,9 & 5,1 & 6,3 & 7,8 & 0,8 & 5,0 \\
\hline 444 & 0,9 & 5,5 & 6,7 & 5,7 & & 4,7 \\
\hline 704 & 1,0 & 4,9 & 6,4 & 7,2 & & 4,9 \\
\hline Átlag (3) & 0,9 & 4,8 & 6,0 & 6,4 & 0,4 & 4,5 \\
\hline \multicolumn{7}{|c|}{$\mathrm{S}(\mathrm{kg} / \mathrm{ha})$} \\
\hline 87 & 1,1 & 2,4 & 2,8 & 2,7 & & 2,2 \\
\hline 214 & 1,1 & 3,2 & 4,3 & 5,4 & 0,6 & 3,5 \\
\hline 444 & 1,1 & 4,3 & 5,9 & 7,5 & & 4,7 \\
\hline 704 & 1,3 & 4,1 & 6,5 & 8,2 & & 5,0 \\
\hline Átlag (3) & 1,2 & 3,5 & 4,9 & 6,0 & 0,3 & 3,8 \\
\hline
\end{tabular}

A 9. táblázat folytatása a következó oldalon... 
A 9. táblázat folytatása...

\begin{tabular}{|c|c|c|c|c|c|c|}
\hline \multirow{2}{*}{$\begin{array}{l}\mathrm{AL}-\mathrm{P}_{2} \mathrm{O}_{5} \\
(\mathrm{mg} / \mathrm{kg})\end{array}$} & \multicolumn{4}{|c|}{$\begin{array}{c}\text { N-trágyázás, } \mathrm{N} \text { kg/ha/év } \\
\text { (1) }\end{array}$} & \multirow{2}{*}{$\begin{array}{l}\mathrm{SzD}_{5 \%} \\
(2)\end{array}$} & \multirow{2}{*}{$\begin{array}{l}\text { Átlag } \\
(3)\end{array}$} \\
\hline & 0 & 100 & 200 & 300 & & \\
\hline \multicolumn{7}{|c|}{$\mathrm{NO}_{3}-\mathrm{N}(\mathrm{kg} / \mathrm{ha})$} \\
\hline 87 & 0,1 & 1,5 & 4,9 & 6,7 & & 3,3 \\
\hline 214 & 0,1 & 0,9 & 5,4 & 8,0 & 0,6 & 3,6 \\
\hline 444 & 0,1 & 0,8 & 5,1 & 4,7 & & 2,7 \\
\hline 704 & 0,1 & 0,3 & 4,1 & 5,5 & & 2,5 \\
\hline Átlag (3) & 0,1 & 0,8 & 4,9 & 6,2 & 0,3 & 3,9 \\
\hline \multicolumn{7}{|c|}{$\mathrm{Sr}(\mathrm{g} / \mathrm{ha})$} \\
\hline 87 & 5 & 20 & 25 & 25 & & 19 \\
\hline 214 & 7 & 38 & 50 & 64 & 6 & 40 \\
\hline 444 & 8 & 48 & 71 & 80 & & 52 \\
\hline 704 & 9 & 53 & 78 & 95 & & 59 \\
\hline Átlag (3) & 7 & 40 & 56 & 66 & 3 & 42 \\
\hline
\end{tabular}

Megjegyzés: Fe 34-405, Mn 25-354, Al 18-210, Sr 5-95, Zn 7-89, B 2-20, Ba és Cu 1-15, Mo 0,74,0, Ni 0,1-1,4, Cd 0,01-0,11 g/ha között ingadozott az N és P ellátottság függvényében. Az As, $\mathrm{Hg}, \mathrm{Cr}$, Se és Co g/ha kimutatási határ alatt.

Table 9. The effect of $\mathrm{N}$ and $\mathrm{P}$ supply levels on the element uptake on 22/05/2007 (Calcareous loamy chernozem, Nagyhörcsök, Mezőföld region). (1) $\mathrm{N}$ fertilisation, $\mathrm{kg} \mathrm{ha}^{-1}$ year $^{-1}$, (2) $\mathrm{LSD}_{5 \%}$, (3) Mean. Note: The following ranges were observed depending on the $\mathrm{N}$ and $\mathrm{P}$ supply levels: $\mathrm{Fe}$ 34-405, Mn 25-354, Al 18-210, Sr 5-95, Zn 7-89, B 2-20, Ba and Cu 1-15, Mo 0.7-4.0, Ni 0.11.4, Cd 0.01-0.11 $\mathrm{g} \mathrm{ha}^{-1}$. The $\mathrm{g} \mathrm{ha}^{-1}$ levels of As, $\mathrm{Hg}, \mathrm{Cr}$, Se, Co were below the detection level.

\section{IRODALOM}

Barcsák Z.: 1999. A gyepek tápanyagellátása. [In: Füleky Gy. (szerk.) Tápanyaggazdálkodás.] Mezôgazda Kiadó. Budapest. 522-535.

Baskay T. B.: 1962. Legelô- és rétmúvelés. Mezôgazdasági Kiadó. Budapest.

Bánszki T.: 1988. NPK mútrágya mennyiségi és aránykísérlet intenzív telepített gyepen. Növénytermelés. 37. 3: 247-257.

Bánszki T.: 1997. Telepített gyep NPK mútrágyázása csernozjom talajon. Növénytermelés. 46. 5: 499-508.

Bergmann, W.: 1992. Nutritional Disorders of Plants. Gustav Fischer Verlag. JenaStuttgart-New York.

Bíró J.: 1928. A legelőgazda könyve. Földmúvelésügyi Minisztérium. Budapest.

Csathó P.: 1992. K- és P hatások kukoricában meszes csernozjom talajon. Agrokémia és Talajtan. 41: 241-260. 
Csathó P.: 2004. A talaj-növény rendszer tápelemforgalmának agronómiai és környezetvédelmi vonatkozásai. Akadémiai Doktori Értekezés Tézisei. Kézirat. Budapest.

Egnér, H.-Riehm, H.-Domingo, W. R.: 1960. Untersuchungen über die chemische Bodenanalyse als Grundlage für die Beurteilung des Nährstoffzustandes der Böden. II. K. Lantbr. Högsk. Ann. 26: 199-215.

Finck, A.: 1982. Fertilizers and Fertilization. Verlag Chemie. Deerfield Beach. Florida, Basel.

Geisler, G.: 1988. Pflanzenbau. 2. Auflage. Paul Parey. Berlin und Hamburg.

Gericke, S.: 1957. Zehn Fragen der Wiesendüngung. 3. Aufl. Tellus. Essen.

Gericke, S.: 1965. Die Wirkung langjähriger PK-Düngung auf den Wiesen. Die Phosphorsäure. 25: 12

Gruber F.: 1960. Rét és legelő. Mezőgazdasági Kiadó. Budapest.

Gyarmathy Gy.: 1980. A gyepnövények mútrágyázási irányelvei. MÉM Növényvédelmi és Agrokémiai Központ. Budapest.

Harmati I.: 1981. A Duna-Tisza közi sós, lúgos szikesek hasznosítása és javítása gyepgazdálkodással. Agrokémia és Talajtan. 30: 186-199.

Harmati I.: 1997. Intenzív telepített gyep létesítése és mútrágyázása karbonátos szoloncsák-szolonyec szikesen. Növénytermelés. 46. 2: 191-202.

Horváth R.-Prohászka K.: 1976. Adatok a rét-legelő növényzetének tápelem-tartalmáról. Növénytermelés. 23. 1: 51-56.

Kádár I.: 1992. A növénytáplálás alapelvei és módszerei. MTA Talajtani és Agrokémiai Kutató Intézete. Budapest. 1-398.

Kádár I.: 2004. Mútrágyázás hatása a telepített gyep ásványi elemtartalmára. 3. Gyepgazd. Közl. 2: 57-66.

Kádár I.: 2008. Mútrágyahatások vizsgálata 4. éves telepített gyepen. Elemfelvétel, elemforgalom. Növénytermelés. 57. 1:9-20.

Kádár I.: 2010. Mútrágyahatások értékelése tartamkísérletben telepített gyepen. Agrokémia és Talajtan. 59: 295-314.

Kádár I.-Gyốri Z.: 2004. Mútrágyázás hatása a gyepszéna takarmányértékére és tápanyag-hozamára. 2. Gyepgazd. Közl. 2: 46-56.

Kádár I.-Gyôri Z.: 2005. Mútrágyázás hatása a telepített gyep aminosav tartalmára és hozamára. 5. Gyepgazd. Közl. 3: 11-20.

Kádár I.-Vinczeffy I.-Ragályi P.: 2010. Mútrágyahatások vizsgálata 6. éves telepített gyepen. Gyepgazd. Közl. (In Press).

Klapp, E.: 1951. Einfluss der Schnitthäufigkeit auf die Wurzeltrockenmasse. Leistung. Bewurzelung und Nachwuchs einer Grassnarbe unter verschieden häufiger Mahd und Beweidung. Z. Acker- und Pflbau. 90: 269-286.

Klapp, E.: 1971. Wiesen und Weiden. P. Parey. 4. Auflage. Berlin.

Lakanen, E.-Erviö, R.: 1971. A comparison of eight extractants for the determination of plant available microelements in soils. Acta Agr. Fenn. 123: 223-232.

McLean, E. O.-Adams, D.-Franklin, R. E.: 1956. Cation exchange capacities of plant roots as related to their nitrogen contents. Proc. Soil Sci. Soc. Am. 20: 345-347. 
Mucsi I.: 1996. A legelő állatok (réz) anyagcsere betegségeinek kialakulása. [In: Vinczeffy I. (szerk.) Gyepgazdálkodási szakülés.] 13. DGYN. DE Mezőgazdasági Kar. Debrecen.127.

Nagy, G.: 2008. Spring phenological development of perennial ryegrass and its response to annual weather conditions. Cereal Res. Commun. 36: 787-790.

Németh T.-Kádár I.: 1999. Nitrát bemosódásának vizsgálata és a N-mérlegek alakulása egy mútrágyázási tartamkísérletben. Növénytermelés. 48. 4: 377-386.

Raymond, W. F.-Spedding, C. R. W.: 1965. The effect of fertilizers on the nutritive value and production potential of forages. Proc. Fertil. Soc. N. 88: 34. p.

Romasev, P. I.: 1960. Luga i pasztviscsa. [In: Katalümov, M. V. (szerk.) Szpravocsnyik po mineral'nüm udobrenijam.] Gosz. Izd. Sz/h. Literaturü. Moszkva. 331-336.

SzabóJ.: 1977. Gyepgazdálkodás. Mezógazdasági Kiadó. Budapest.

Thamm F.-né: 1990. Növényminták nitráttartalmának meghatározását befolyásoló tényezók vizsgálata. Agrokémia és Talajtan. 39: 191-206.

Tölgyesi Gy.: 1965. A keszthelyi lápon termett szálastakarmányok réz és molibdén tartalmának takarmányozási vonatkozásai. Magyar Állatorvosok Lapja. 20: 502-506.

Vinczeffy I.: 1998. Lehetôségeink a legeltetéses állattartásban. Tanulmány. 16. Debreceni Gyepgazdálkodási Napok. DATE. Debrecen.

Voisin, A.: 1961. Lebendige Grasnarbe. BLV Verlagsgesellschaft. München.

Voisin, A.: 1964. A talaj és a növényzet, az állat és az ember sorsa. Mezőgazdasági Kiadó. Budapest.

Voisin, A.: 1965. Fertilizer application. Soil, plant, animal. Crosby Lockwood. London. Whitehead, D. C.: 1970. The role of nitrogen in grassland productivity. Commonwealth Bureau of Pastures and Field Crops. Hurley, Berkshire. Bulletin N. 48: 202.

Wagner, P.: 1909. Versuche über Wiesendüngung. Arbeiten der DLG. N. Berlin. 162.

Wagner, P.: 1921. Die Düngung der Wiesen nach den Ergebnissen von 4-14. jährigen Versuchen. Arbeiten der DLG. N. Berlin. 318.

A szerzôk levelezési címe - Adress of the authors:

Dr. Kádár Imre-Ragályi Péter

MTA Talajtani és Agrokémiai Kutatóintézet

Budapest

Herman O. u. 15.

H-1022 